\title{
Australian Journal of \\ Crop Science \\ Absorption of nutrients and chemical reconditioning of red latosol by cover plants cultivated in Amazon environment
}

\author{
Érica de Oliveira Araújo ${ }^{1}$, Jiovane Anderson da Silva Ribeiro ${ }^{2}$, Daniele Jesus Venturim², José Vanor Felini \\ Catânio ${ }^{3}$, Vitório Macieski Neto ${ }^{1}$, Diogo de Souza Freitas ${ }^{2}$, Aline Ottes Moreira ${ }^{2}$, Nélio Ranieli Ferreira de \\ Paula ${ }^{1}$, José Henrique de Souza Costa ${ }^{4}$, Willian Junior Silva Costa ${ }^{4}$, Klariston Rodrigues dos Santos ${ }^{4}$
}

\author{
${ }^{1}$ Agronomy, Department of Agriculture, Federal Institute of Education, Science and Technology, Rondonia State, \\ Campus Colorado do Oeste, Brazil \\ ${ }^{2}$ Agronomic Engineering, Department of Agronomy, Federal Institute of Education, Science and Technology, \\ Rondonia State, Campus Colorado do Oeste, Brazil \\ ${ }^{3}$ Animal Production, Department of Integration, Teaching, Research and Extension, Federal Institute of Education, \\ Science and Technology, Rondonia State, Campus Colorado do Oeste, Brazil \\ ${ }^{4}$ Agriculture, Department of Agriculture, Federal Institute of Education, Science and Technology, Rondonia State, \\ Campus Colorado do Oeste, Brazil
}

\section{*Correspondence: erica.araujo@ifro.edu.br}

\begin{abstract}
Maintaining the balance of the system using cover crops is a promising alternative for the Amazon region. In this context, the present study aimed to evaluate the absorption of nutrients by cover crops and the reconditioning of soil chemical attributes after management with different cover crops. The experiment was conducted in the experimental area of the Federal Institute of Education, Science and Technology of Rondonia, Colorado do Oeste Campus, in the municipality of Colorado do Oeste, RO, Brazil. The experimental design used was completely randomized, arranged in a $7 \times 4$ factorial scheme, consisting of seven species of cover crops (Crotalaria spectabilis, Crotalaria breviflora, Crotalaria ochroleuca, Mucuna aterrima, Mucuna pruriens, Dolichos lablab and Canavalia ensiformis) and four sampling depths $(0-10 \mathrm{~cm}, 10-20 \mathrm{~cm}, 20-30 \mathrm{~cm}$ and $30-40 \mathrm{~cm})$, with four replicates. The results concluded that the cultivation of Crotalaria spectabilis, Crotalaria ochroleuca and Crotalaria breviflora provided higher dry matter yield. The species Dolichos lablab stood out in the accumulation of nitrogen, phosphorus, calcium and sulfur in the leaves at full flowering. The contents of organic matter, total carbon, $\mathrm{C} / \mathrm{N}$ ratio, $\mathrm{N}$-total, $\mathrm{P}, \mathrm{K}, \mathrm{Ca}^{2+}$ and $\mathrm{Mg}^{2+}$ of the soil were higher at the depth of 0-10 cm with a decrease in subsurface layers. The species Dolichos lablab and Mucuna pruriens are efficient in terms of supplying organic matter, organic carbon, $\mathrm{C} / \mathrm{N}$ ratio, $\mathrm{N}$-total, phosphorus, calcium and $\mathrm{Ca} / \mathrm{Mg}$ ratio of the soil, promoting a direct impact on the fertility of its surface layers up to $10 \mathrm{~cm}$ deep. Cultivation of Crotalaria breviflora and Crotalaria spectabilis caused variation in soil exchangeable bases, being directly correlated with the values of $\mathrm{pH}, \mathrm{SB}$ and $\mathrm{CEC}$.
\end{abstract}

Keywords: Fabaceae, Green Manure, Nutrient Cycling, Organic Matter, Organic Carbon, N-Total, Sustainable soil management.

Introduction

The dominant soils of the Amazon biome, notably the Latossolos (Oxisols), are of clayey texture in general, wellstructured with high aggregate stability, despite being highly weathered, acidic and poor in nutrients that are essential to plants. Under anthropic conditions, inadequate management of these soils affects their organic matter content and structure, reducing nutrient availability and aggregation (Santos et al., 2011).

Among the available technologies to manage tropical soils, the cultivation of cover crops preceding maize or soybean stands out, as it can result in increased yield and maintenance of the system's balance because maize and soybean are the two main grain crops in terms of planted area in Rondônia (Conab, 2020).
Legumes stand out among the species used as cover crops in crop succession or rotation systems, especially due to the potential for biomass production and nitrogen addition. It is also important for carbon sequestration in the soil (Sisti et al., 2004), providing more favorable conditions for carbon stock in the upper layers andin its deeper layers, over the time of adoption. The inclusion of legumes as green manure provides the nitrogen preferably used by microorganisms that synthesize the most stable fractions of soil organic matter (SOM) (Santos et al., 2012). This plant material deposited in the soil becomes part of its matrix, constituting the SOM, showing a varied and complex nature. These effects may mean a form of agriculture with low greenhouse gas emissions, which contributes to mitigating the effects of 
climate change and promoting increased sustainability of agroecosystems (Basches et al., 2014; Mukherjee; Lal, 2015). Thus, cultivating cover crops is a management practice that can return to the soil, part of what has been lost over decades of conventional cultivation.

The success in the adoption of management systems that include cover crops in the Amazon biome depends on climatic conditions, since there is a significant influence on the acceleration of the decomposition of plant residues with consequent reduction in SOM accumulation. The concentrations of nitrogen and organic compounds such as lignin, hemicellulose and cellulose regulate residue decomposition rate and affect the dynamics of fractions and accumulation of SOM (Santos et al., 2012; Carvalho et al., 2015). In addition, the deposition of plant residues over the years favored the increase in humic acid concentration, which together with the high annual rainfall, concentrated in the warmer months. This intensifies the biodegradation of unstable SOM fractions, with faster transformation from fulvic acid to humic acid, mainly in cover plants with lower lignin content (Santos et al., 2012).

In the Northwest region of the Amazon, especially in the state of Rondônia, there is little substantiated information on the operation of this technology in the maintenance or construction of soil fertility, which becomes fundamental for the success of the different production systems and an effective strategy to promote better soil conditioning. Thus, research focused on deepening this knowledge will serve as a scientific basis for a new technological process aimed at agricultural production in the Amazon region, contributing to the development and consolidation of research in the state of Rondônia. Therefore, the present study aimed to evaluate the absorption of nutrients by cover crops and the reconditioning of soil chemical attributes after management with different cover crops.

\section{Results and discussion}

\section{Dry matter production and chemical composition of the shoots of cover crops}

There was a significant difference $(p \leq 0.05)$ between cover crops for dry matter production and nutrient content (Figure 2 and Table 3 ).

The cultivation of Crotalaria spectabilis led to the best results for dry matter production (13.2 t.ha $\left.{ }^{-1}\right)$, but this species did not differ statistically from Crotalaria ochroleuca (10.2 t.ha-1) and Crotalaria breviflora (8.3 t.ha-1) (Figure 2). Such increase in dry matter in the soil can promote significant improvements in its physical and chemical characteristics and maintenance and/or elevation of soil organic matter content, maintenance of soil temperature, and act as a physical barrier against infestation of invasive plants, besides favoring the development and yield of agricultural species in subsequent crops (Andrade Neto et al., 2008; Boer et al., 2008). On the other hand, the lowest dry matter yields were obtained by the species Canavalia ensiformis (4.7 t.ha- $\left.{ }^{-1}\right)$, Dolichos lablab (5.8 t.ha-1) and Mucuna aterrima (5.2 t.ha-1) (Figure 2), being below the minimum amount of dry matter deposited annually necessary for adequate soil cover in no-tillage system. The low initial rainfall observed for the region during plant establishment (first 30 days - November) was possibly related to the low dry matter production by these cover plants (Figure 1). These results partially corroborate those obtained by Pereira et al. (2017), who observed high dry matter production for Crotalaria spectabilis and Canavalia ensiformis and low dry matter production for Mucuna aterrima, which makes it possible to infer that the capacity for dry matter production is directly related to edaphoclimatic conditions, soil fertility and agricultural year. It was observed that, even with low dry matter production, the species Canavalia ensiformis and Mucuna aterrima were able to absorb and accumulate the highest nitrogen contents in their leaves at full flowering, about $25.28 \mathrm{~g} \mathrm{~kg}^{-1}$ and 24.34 $\mathrm{g} \mathrm{kg}^{-1}$, respectively, differing statically from the other cover crops. The lowest nitrogen contents were obtained by Crotalaria spectabilis, Crotalaria breviflora and Crotalaria ochroleuca, in an inverse relationship with dry matter production (Table 3 ). The results obtained are similar to those observed by Pereira et al. (2017), who studied nutrient cycling by different cover crops and found shoot $\mathrm{N}$ contents $29.50 \mathrm{~g} \mathrm{~kg}^{-1}$ in Canavalia ensiformis and $30.0 \mathrm{~g} \mathrm{~kg}^{-1}$ in Mucuna aterrima. Barros et al. (2013), Teodoro et al. (2011) and Padovan et al. (2011) indicate Canavalia ensiformis as an excellent cover species because it has high capacity for extracting nutrients from the soil and performing biological nitrogen fixation by the symbiotic association with bacteria of the genus Rhizobium. In addition, based on the results obtained, Canavalia ensiformis and Mucuna aterrima will contribute to high nutrient incorporation, promoted later by biomass decomposition.

The species Dolichos lablab stood out for the accumulation of nitrogen, phosphorus, calcium and sulfur in the leaves, with significantly higher contents than the other cover plants. This highlights its ability to accumulate N, P, Ca and S in the leaf tissues, with no close relationship with the supply of shoot dry matter (Table 3).

For potassium content, there was no significant difference between the cover plants. In areas with low potassium contents, it is important to use soil cover plants because of their capacity for cycling, accumulating and supplying this nutrient to the subsequent crop, which favors the agricultural systems (Teodoro et al., 2011).

Canavalia ensiformis had the highest calcium content (16.70 $\mathrm{g} \mathrm{kg}^{-1}$ ), corroborating the result found by Padovan et al. (2011) (being $17.25 \mathrm{~g} \mathrm{~kg}^{-1}$ ). According to these authors, the phenological stage suitable for Canavalia ensiformis management is during the formation of the first pods, which corresponds to 90 days after emergence, because at this stage there is a significant accumulation of nutrients in the shoots after flowering, mainly nitrogen, potassium and calcium. The stage at which cover crops should be managed is important so that their use does not become harmful to the next crop, mainly due to the deposition of viable seeds and natural re-sowing in the subsequent crop Pereira et al. (2017). Calegari (1995) green manure as cover plant and noted that they should be mowed or desiccated at the flowering stage, as it enables satisfactory dry matter accumulation on soil surface. Nevertheless, according to Padovan et al. (2011 and 2014), cover plants (Canavalia ensiformis and Crotalaria sp.) intended for green manure should be managed at the beginning of the grain formation stage because it enhances the accumulation of dry matter and nutrients in the shoots. Besides, there is no risk of competition with the subsequent crop, due to the nondeposition of viable seeds of cover crops in the areas of cultivation. This information may explain the low contents of 
$\mathrm{N}$ by the cover plants Crotalaria spectabilis, Crotalaria breviflora and Crotalaria ochroleuca.

Crotalaria spectabilis, Crotalaria breviflora and Crotalaria ochroleuca showed the highest contents of magnesium, which emphasizes the efficiency of Crotalaria species in cycling this nutrient (Table 3 ). These results confirm those reported by Pereira et al. (2017).

\section{Soil chemical attributes and management with different cover plants}

Regarding soil chemical attributes, the results showed significant effects $(p \leq 0.01)$ of the double interaction between cover plants and sampling depth on SOM, organic carbon and $\mathrm{N}$-total (Table 6), phosphorus, calcium, magnesium and $\mathrm{Ca} / \mathrm{Mg}$ ratio (Table 7), $\mathrm{pH}, \mathrm{SB}$ and $\mathrm{CECpH} 7$ (Table 8). The other results did not show significant effect of the interaction and presented independently for the different cover plants (Table 4 and 5) and different sampling depths (Figure 3 and 4).

At the different sampling depths, there was significant response $(p<0.01)$ of SOM, total carbon, $C / N$ ratio and $N$ total contents in the soil. The mean values of these variables at the $0-10 \mathrm{~cm}$ depth were higher and statistically different from those found at the other sampling depths. These data make it possible to infer that in this first period of evaluation of the no-tillage system in crop succession, there was a significant effect up to the depth of $10 \mathrm{~cm}$. This includes the reduction in the soil contents of SOM, organic carbon, $\mathrm{C} / \mathrm{N}$ ratio and $\mathrm{N}$-total in subsurface layers (Figure $3 \mathrm{~A}, 3 \mathrm{~B}, 3 \mathrm{C}$ and 3D). In systems such with reduced soil activity and crop succession, the increase in SOM and total carbon contents in the most superficial soil layer is mainly associated with the increase in the supply of plant material to the soil due to the management of different cover crops (Figure 2). It also participate in improvement of soil physical quality and increase in soil organic matter humification, especially in the most surface soil layer $(0-10 \mathrm{~cm})$ (Figure $3 \mathrm{~A}$ and $3 \mathrm{~B})$. Thus, it is important to point out that, as the soil structure is strengthened by the adoption of these management systems with little turning, the contents of SOM, organic carbon, $\mathrm{C} / \mathrm{N}$ ratio and $\mathrm{N}$-total will increase, enabling even the stabilization of organic matter in the long term, as reported by Conceição et al. (2013) and Lima et al. (2016). Thus, for the edaphoclimatic conditions under which the experiment was conducted, the accumulation of total organic carbon essentially depends on the stabilization of soil organic matter for subsequent effects in upper sampling layers. Lima et al. (2016) and Faccin et al. (2016) stated that reduced tillage systems are more efficient at accumulating carbon in the most superficial soil layer $(0-30 \mathrm{~cm}$ and $0-5 \mathrm{~cm}$, respectively), whereas that organic matter stabilization is important for maintaining the total organic carbon contents of the soil. Consequently, a large amount of carbon is accumulated in systems that are associated with large supplies of plant residues This corroborates the results by Salton et al. (2011), who studied carbon content and dynamics in soil in crop-livestock integration systems and found higher contents in the surface soil layers with reduction in subsurface. Ensinas et al. (2016) verified that the greater the addition and accumulation of plant residues on soil surface, the greater the organic carbon supply expected to occur in the surface layer.
$\mathrm{N}$-total contents in the soil decreases with the sampling depth, which was expected, because of the close relationship between the $\mathrm{N}$ contents in the soil and higher organic activity in surface, i.e., in the $0-10 \mathrm{~cm}$ layer (Figure $3 D$ ). In natural systems, the main routes of entry of $N$ into soils are the decomposition and mineralization of organic matter (which varies according to the type of treatment), rainwater and washing water of living and dead biomass accumulated on the soil and from the vegetation (Smethus, 2000). Thus, the combination of dry matter yield with higher $\mathrm{N}$ contents resulted in higher $\mathrm{N}$ content in the soil (Figure 3D). Besides, the more accelerated decomposition of organic matter due to the low $\mathrm{C} / \mathrm{N}$ ratio was observed in legume crops, since several studies show that these species accumulate more nutrients and release them faster during their decomposition.

The result of the variance analysis for soil chemical attributes showed an individual effect of sampling depth on phosphorus, potassium, calcium and magnesium contents in the soil, being clear that there were significant increments $(p<0.01)$ in the contents of $\mathrm{P}, \mathrm{K}, \mathrm{Ca}$ and $\mathrm{Mg}$ in the $0-10 \mathrm{~cm}$ layer compared to the other sampling layers, but there was no significant difference between the subsurface sampling layers (Figure 4A, 4B, 4C and 4D). Among the mean values of $P$ available in the soil at the sampling depth of $0-10 \mathrm{~cm}$, the content was equal to $7.79 \mathrm{mg} \mathrm{dm}^{-3}$, against $4.14 \mathrm{mg} \mathrm{dm}^{-3}$, $3.80 \mathrm{mg} \mathrm{dm}^{-3}$ and $4.49 \mathrm{mg} \mathrm{dm}^{-3}$, respectively, in the layers of $10-20 \mathrm{~cm}, 20-30 \mathrm{~cm}$ and $30-40 \mathrm{~cm}$ depth (Figure $4 \mathrm{~A}$ ). However, the mean values of $\mathrm{K}$ available in the soil in the 0 $10 \mathrm{~cm}$ layer were $157.32 \mathrm{mg} \mathrm{dm}^{-3}$, differing statistically from those found in the subsurface layers of $10-20 \mathrm{~cm}, 20-30 \mathrm{~cm}$ and $30-40 \mathrm{~cm}$, which were equal to $63.40 \mathrm{mg} \mathrm{dm}^{-3}, 51.99 \mathrm{mg}$ $\mathrm{dm}^{-3}$ and $45.81 \mathrm{mg} \mathrm{dm}^{-3}$, respectively (Figure 4B). It is worth mentioning that the increments in $\mathrm{P}$ and $\mathrm{K}$ contents in the 0 $10 \mathrm{~cm}$ layer under conditions of management with different cover plants were on the order of $94.75 \%$ and $92.02 \%$, respectively, compared to the control based on the initial analysis of soil fertility before the experiment (Table 1 ). The accumulation of nutrients, such as $P$ and $K$ in the surface layer, results from their release in greater quantity due to the decomposition of plant residues and reduction in their fixation because of the lower contact of these elements with soil constituents (Sidiras and Pavan, 1985). However, these values are considered low and tend to decrease as the depth increases in the profile, which reflects their limited mobility in the soil. This is clearly observed in the experiment, in which there was a close and direct relationship of the contents of these nutrients in subsurface with the contents of SOM.

Regarding calcium and magnesium contents in the soil (Figure 4C and 4D), the values of exchangeable $\mathrm{Ca}^{2+}(31.77$ $\left.\mathrm{mmol} \mathrm{dm}^{-3}\right)$ and exchangeable $\mathrm{Mg}^{2+}\left(18.66 \mathrm{mmol} \mathrm{dm}^{-3}\right)$ at the depth of $0-10 \mathrm{~cm}$ were higher than those found at depths of $10-20 \mathrm{~cm}, 20-30 \mathrm{~cm}$ and $30-40 \mathrm{~cm}$, respectively. Although there is a significant difference, it is important to point out that these contents of $\mathrm{Ca}^{2+}$ and $\mathrm{Mg}^{2+}$ are considered high for crops, according to Raij et al. (1997). Silva et al. (2017) studied the effect of cover crops on the chemical quality of a Latossolo distrófico (Oxisol) under notillage and observed increments in $\mathrm{P}, \mathrm{K}, \mathrm{Ca}$ and $\mathrm{Mg}$ contents in the surface layers of the soil, with reductions in subsurface layers.

The species Dolichos lablab and Mucuna pruriens were statistically superior $(p \leq 0.01)$ to the other cover plants 
regarding the supply of organic matter, organic carbon, $\mathrm{C} / \mathrm{N}$ ratio, $\mathrm{N}$-total, phosphorus and $\mathrm{Ca} / \mathrm{Mg}$ ratio (Table 4$)$. These results are related to the higher shoot dry matter production by Mucuna pruriens (Figure 2) and higher accumulation of nitrogen, phosphorus and calcium in the leaves by Dolichos lablab (Table 3), which favor the cycling of nutrients via decomposition. Thus, the increase in $\mathrm{N}$ and $\mathrm{P}$ contents are directly correlated with SOM contents in areas cultivated with Mucuna pruriens and Dolichos lablab. Studies demonstrate that the increase in SOM contributes to increasing $P$ content in the soil (Canellas et al., 2003; Theodoro et al., 2003; Almeida et al., 2005; Cardoso et al., 2013) due to the return of $P$ forms accumulated in plant biomass and greater complexation of $\mathrm{Al}$ and Fe ions in the soil solution (Azevedo et al., 2007).

Regarding $\mathrm{Ca}^{2+}$ and $\mathrm{Mg}^{2+}$, the species Mucuna pruriens, Crotalaria breviflora and Crotalaria spectabilis were significantly efficient in increasing their contents in soil, not differing statistically from one another (Table 4). The significant increase was observed in $\mathrm{pH}$ of areas cultivated with Crotalaria breviflora and Crotalaria spectabilis, compared to the other cover plants. This insights the efficiency of these species in absorbing and accumulating $\mathrm{Ca}^{2+}$ and $\mathrm{Mg}^{2+}$ in their tissues, enabling the cycling of these nutrients, and consequently, reductions in $\mathrm{Al}$ content, potential acidity, saturation by $\mathrm{Al}^{3+}$, and increase in the soil contents of basic cations $\left(\mathrm{Ca}^{2+}\right.$ and $\left.\mathrm{Mg}^{2+}\right), \mathrm{SB}, \mathrm{CEC}$ and $\% \mathrm{~V}$ (Table 5). In addition, the supply of organic material in the areas under cover crops contributes to the increase in $\mathrm{pH}$ and reduction in $\mathrm{Al}^{3+}$ contents. In a Latossolo amarelo (Oxisol) under no-tillage in the Cerrado of Maranhão, Bressan et al. (2013) also observed positive effects of soil cover on soil chemical attributes, especially $\mathrm{pH}, \mathrm{Al}^{3+}$ contents, $\mathrm{Al}^{3+}$ saturation, and $\mathrm{Ca}^{2+}$ and $\mathrm{Mg}^{2+}$ contents.

The decomposition of the double interaction between cover plants and different sampling depths revealed that the species Dolichos lablab and Mucuna pruriens were statistically different $(p<0.01)$ from the other cover crops regarding the contents of SOM, organic carbon and $\mathrm{N}$-total at the different sampling depths $(0-10 \mathrm{~cm}, 10-20 \mathrm{~cm}, 20-30$ $\mathrm{cm}$ and $30-40 \mathrm{~cm})$. We also observed a reduction in SOM, organic carbon and $\mathrm{N}$-total contents in subsurface (Table 6). In the $0-10 \mathrm{~cm}$ layer, the cultivation of Dolichos lablab and Mucuna pruriens resulted in the highest accumulations of organic matter, total carbon and N-total, while the lowest values were obtained by the species Mucuna aterrima (Table $6)$. The mean difference between Dolichos lablab and Mucuna pruriens plants in relation to organic matter supply at the different depths was in the order of $121 \%$ in the $0-10$ $\mathrm{cm}$ layer, $205 \%$ in the $10-20 \mathrm{~cm}$ layer, $124 \%$ in the $20-30 \mathrm{~cm}$ layer and $72 \%$ in the $30-40 \mathrm{~cm}$ layer, when compared to Mucuna aterrima (lowest values obtained). For the total carbon and $\mathrm{N}$-total contents, the values represent average increments of $12 \%$ and $112 \%$ in the $0-10 \mathrm{~cm}$ layer, $206 \%$ and $61 \%$ in the $10-20 \mathrm{~cm}$ layer, $121 \%$ and $71 \%$ in the $20-30 \mathrm{~cm}$ layer and $100 \%$ and $27 \%$ in the $30-40 \mathrm{~cm}$ layer, respectively. Accumulation of total carbon in the $0-10 \mathrm{~cm}$ layer, i.e. in the surface layer, results from the transformation of the shoots of the plants and their roots concentrated in the layer and that what is below $10 \mathrm{~cm}$ is derived from roots, root exudates and soluble organic carbon leached from the upper layers. The deeper tap root system of the cover legumes evaluated may have led to the accumulation of $O C$ and $\mathrm{N}$ total in the layers below $10 \mathrm{~cm}$, but at percentages lower than in the surface layer of $0-10 \mathrm{~cm}$. Bertiol (2014) observed that the increase in organic carbon and $\mathrm{N}$-total in the soil was favored by the cultivation of legumes, especially Mucuna pruriens. Marques et al. (2012) quantified the concentrations of dissolved organic carbon (DOC) in soil of primary forest of the Amazon, at three topographic positions, and in areas of pasture, secondary succession and agroforestry system up to the depth of $2 \mathrm{~m}$. They obtained the highest DOC contents in the surface layers in all studied environments, significantly differing from the other depths. The OC reservoir in soils reflects several biological (biodegradation/decomposition, biotransformation), chemical (adsorption, complexation, photodegradation) and physical (leaching and eluviation) processes that, in turn, are moderated by biotic and abiotic factors that include soil $\mathrm{pH}$, OC and clay content, microbial activity, temperature and moisture (Bolan et al., 2011)

The cultivation of legume cover species led to variation in the contents of phosphorus, magnesium, calcium and $\mathrm{Ca} / \mathrm{Mg}$ ratio at a depth of $0-10 \mathrm{~cm}$, with reductions in upper sampling layers (Table 7). The cover crop Dolichos lablab caused significant variation compared to the other cover species in the $\mathrm{P}$ content available in the soil. As observed in Table 7 for $\mathrm{pH}$, the values did not exceed 5.37 for Dolichos lablab and there was a reduction in subsurface, i.e., a higher level of acidity, which led to no statistical difference in $\mathrm{P}$ contents in layers below $10 \mathrm{~cm}$ (Table 6). The ideal $\mathrm{pH}$ for better availability of various nutrients, such as phosphorus, calcium and magnesium, varies between 5.5 and 6.5 for most crops, which justifies the reduction in the contents of these nutrients at depths greater than $10 \mathrm{~cm}$. The available $P$ contents in the soil, even under slightly more acidic $\mathrm{pH}$ conditions, as observed in the $0-10 \mathrm{~cm}$ layer, may be related to the fertilizer distribution depth at sowing.

The use of cover crops and other management practices aimed at maintaining or increasing SOM contents can favor the utilization of $P$ by plants. The presence of straw and the higher OM content in the system of reduced soil tillage and in the system of crop succession provide a less oxidative environment, minimizing adsorption reactions and causing a direct impact on the fertility of the surface layer, up to $10 \mathrm{~cm}$ deep (Costa, 2000; Bertiol, 2014). Thus, plants are fundamental in the solubilization of $P$ through the exudation of compounds in the rhizosphere, including organic acids that act on the dissolution of compounds and result in an increase in P-solution (Chien; Menon, 1995).

There was significant effect $(p<0.01)$ of the cover crops Dolichos lablab and Crotalaria spectabilis on the exchangeable $\mathrm{Ca}^{2+}$ content in the soil at the depth of 0-10 $\mathrm{cm}$, which is directly correlated with the values of SB and CEC (Table 8), not differing statistically from the species Mucuna pruriens, Crotalaria breviflora and Crotalaria ochroleuca at the same sampling depth and in subsurface $(10-20 \mathrm{~cm}, 20-30 \mathrm{~cm}$ and $30-40 \mathrm{~cm})$ (Table 7). While Crotalaria spectabilis stood out positively regarding the contents of exchangeable $\mathrm{Mg}^{2+}$ in the $0-10 \mathrm{~cm}$ layer, on the order of $25.97 \mathrm{mmol} \mathrm{dm}^{-3}$, the species Dolichos lablab stood out in terms of $\mathrm{Ca} / \mathrm{Mg}$ ratio in all sampled layers, with a reduction in $\mathrm{Ca} / \mathrm{Mg}$ ratio in the surface layers and higher $\mathrm{Ca} / \mathrm{Mg}$ ratio in subsurface layers, such as $20-30 \mathrm{~cm}$ and $30-$ $40 \mathrm{~cm}$ (Table 7). In the $0-10 \mathrm{~cm}$ layer, the $\mathrm{Ca}^{2+}$ contents were relatively high, showing a reduction with the increase in the sampling depth (even though there was no statistical difference). 
Table 1. Chemical attributes of the soil before installing the experiment at different depths.

\begin{tabular}{|c|c|c|c|c|c|c|c|c|c|c|c|c|c|c|}
\hline \multirow{2}{*}{ Profundidade } & \multirow{2}{*}{$\frac{\mathrm{N}}{\mathrm{mg} \mathrm{dm}}{ }^{-3}$} & \multirow{2}{*}{\multicolumn{2}{|c|}{$\frac{\mathrm{SOM}}{\mathrm{g} \mathrm{dm}^{-3}}$}} & \multirow{2}{*}{$\begin{array}{l}\mathrm{pH} \\
\mathrm{CaCl}_{2}\end{array}$} & $\mathrm{P}$ & $\mathrm{K}$ & $\mathrm{Ca}$ & $\mathrm{Mg}$ & $\mathrm{H}+\mathrm{Al}$ & $\mathrm{Al}$ & SB & CEC & V & $\mathrm{m}$ \\
\hline & & & & & \multicolumn{2}{|c|}{$\mathrm{mg} \mathrm{dm}^{-3}$} & \multicolumn{6}{|c|}{-----------------'mmolc/dm'----------------- } & \multicolumn{2}{|c|}{------\%------ } \\
\hline 0-10 & 2553.5 & 11.4 & 6.62 & 4.9 & 4 & 81.9 & 29 & 8 & 30 & 1 & 40 & 70 & 57 & 2 \\
\hline $10-20$ & 2090.9 & 5.3 & 3.08 & 5.0 & 1 & 58.5 & 36 & 4 & 25 & 1 & 41 & 66 & 62 & 2 \\
\hline $20-30$ & 1848.3 & 4.2 & 2.44 & 5.3 & 1 & 42.9 & 37 & 3 & 20 & 0 & 40 & 60 & 67 & 1 \\
\hline $30-40$ & 1782.3 & 3.1 & 1.0 & 5.5 & 1 & 27.3 & 35 & 2 & 17 & 0 & 37 & 54 & 69 & 1 \\
\hline
\end{tabular}

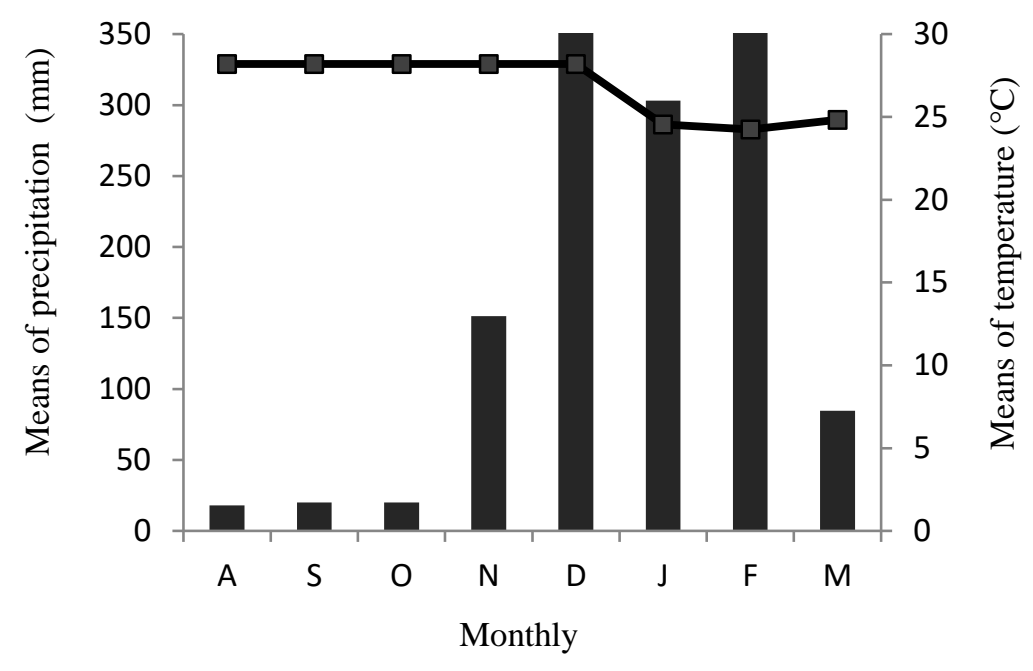

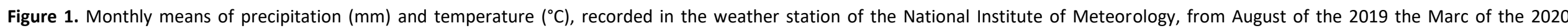
agricultural year. 
Table 2. Species of cover crops (plot treatments), $\mathrm{C} / \mathrm{N}$ ratio indicated in the literature and sowing density used.

\begin{tabular}{llll}
\hline \multicolumn{1}{c}{ Species } & Family & $\mathrm{C} / \mathrm{N}$ ratio & Sementes $\mathrm{m}^{2}$ \\
\hline Crotalaria ochroleuca & Fabaceae & $25-29^{2}$ & 67 \\
Crotalaria spectabilis & Fabaceae & $10-16^{1}$ & 73 \\
Crotalaria breviflora & Fabaceae & $11-18$ & 73 \\
Mucuna aterrima & Fabaceae & $12-21^{1}$ & 9 \\
Mucuna pruriens & Fabaceae & $12-21^{1}$ & 9 \\
Dolichos lablab & Fabaceae & $23-28^{3}$ & 10 \\
Canavalia ensiformis & Fabaceae & $10-16^{1}$ & 11 \\
\hline${ }^{1}$ Wutke et al. (2014); ${ }^{2}$ Fischlerab et al. (1999); ${ }^{3}$ Teodoro et al. (2011). & &
\end{tabular}

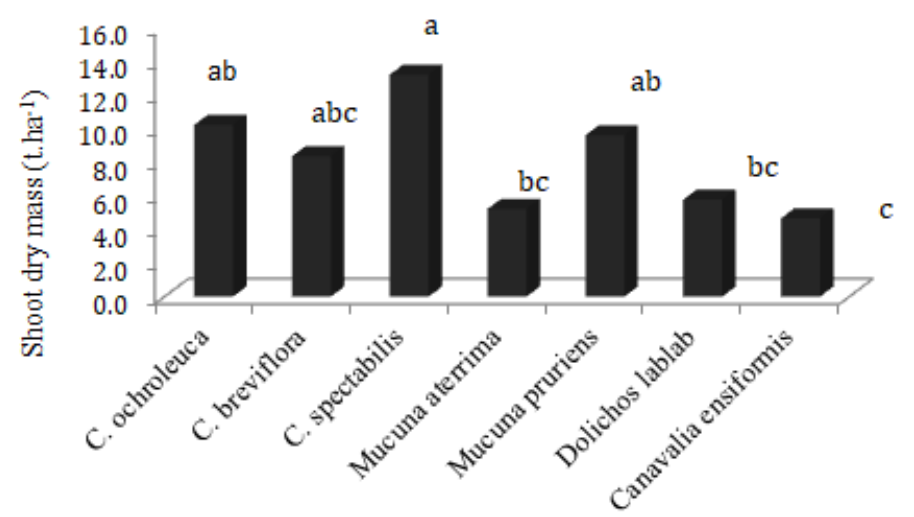

Figure 2. Production of shoot dry mass by different cover plants.

Table 3. Nitrogen $(N)$, phosphorous $(P)$, potassium $(K)$, calcium $(\mathrm{Ca})$, magnesium $(\mathrm{Mg})$ and sulfur $(\mathrm{S})$ content in the full flowering of different cover plants.

\begin{tabular}{lllllll}
\hline Cover plants & $\mathrm{N}$ & $\mathrm{P}$ & $\begin{array}{c}\mathrm{K} \\
\left(\mathrm{g} \mathrm{kg}^{-1}\right)\end{array}$ & $\mathrm{Ca}$ & $\mathrm{Mg}$ & $\mathrm{S}$ \\
\cline { 1 - 5 } Canavalia ensiformis & $25.28 \mathrm{a}$ & $1.87 \mathrm{~b}$ & $13.94 \mathrm{a}$ & $16.70 \mathrm{a}$ & $1.91 \mathrm{bc}$ & $1.12 \mathrm{~b}$ \\
Dolichos lablab & $21.28 \mathrm{abc}$ & $2.45 \mathrm{a}$ & $13.81 \mathrm{a}$ & $14.75 \mathrm{ab}$ & $1.82 \mathrm{~d}$ & $1.78 \mathrm{a}$ \\
Mucuna aterrima & $24.34 \mathrm{ab}$ & $1.77 \mathrm{~b}$ & $13.54 \mathrm{a}$ & $12.43 \mathrm{~cd}$ & $1.78 \mathrm{~d}$ & $1.15 \mathrm{~b}$ \\
Mucuna pruriens & $23.00 \mathrm{ab}$ & $1.88 \mathrm{~b}$ & $11.27 \mathrm{a}$ & $11.95 \mathrm{~d}$ & $2.01 \mathrm{bc}$ & $1.23 \mathrm{~b}$ \\
C. ochroleuca & $19.13 \mathrm{c}$ & $1.55 \mathrm{~b}$ & $14.51 \mathrm{a}$ & $8.17 \mathrm{e}$ & $2.65 \mathrm{a}$ & $1.25 \mathrm{~b}$ \\
C. breviflora & $19.32 \mathrm{c}$ & $1.54 \mathrm{~b}$ & $13.42 \mathrm{a}$ & $13.25 \mathrm{bcd}$ & $2.38 \mathrm{ab}$ & $1.26 \mathrm{~b}$ \\
C. spectabilis & $20.29 \mathrm{bc}$ & $1.68 \mathrm{~b}$ & $14.51 \mathrm{a}$ & $14.55 \mathrm{abc}$ & $2.28 \mathrm{abc}$ & $1.44 \mathrm{ab}$ \\
\hline Mean & 21.81 & 1.82 & 13.57 & 13.12 & 2.12 & 1.32 \\
CV (\%) & 10.85 & 10.93 & 14.30 & 9.26 & 13.93 & 10.80 \\
\hline Means followed by the same letter in the column do not differ statistically by Tukey test at 5\% probability level. cv (Coefficient of variation). & &
\end{tabular}
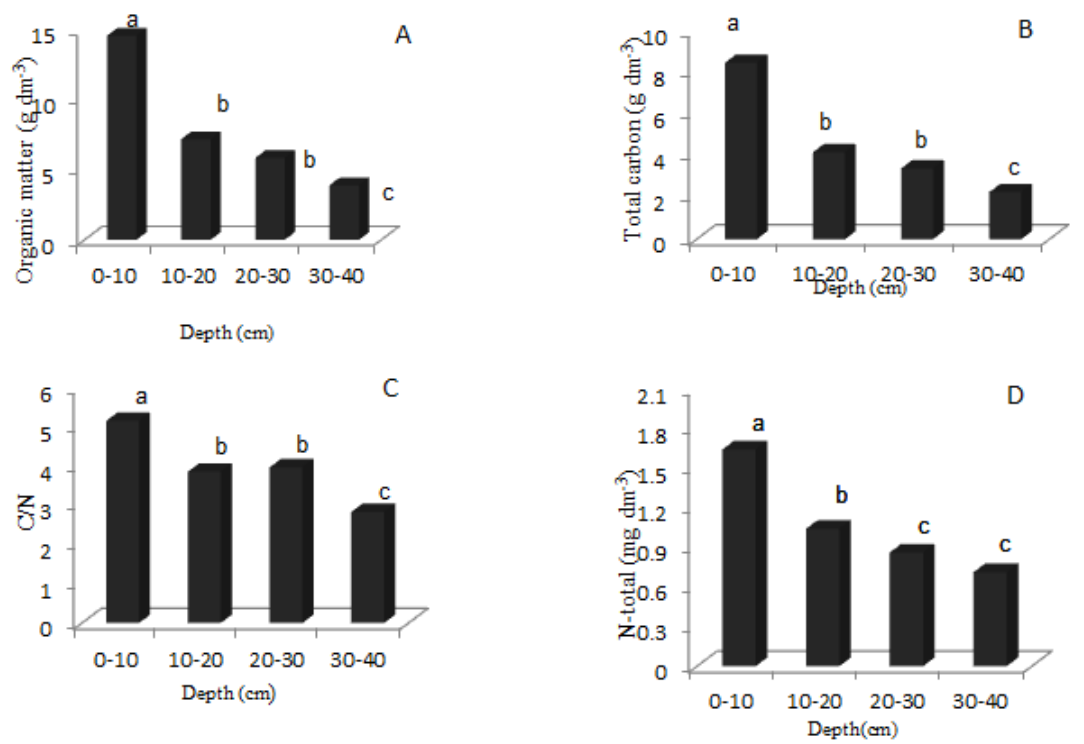

Figure 3. Mean levels of organic matter (A), total carbon (B), C/N (C) and N-total (D) of soil function of different sampling depths. Equal letters on bars do not differ statistically from each other by tukey test at $1 \%$ probability. 
Table 4. Mean values of organic matter $(S O M)$, organic carbon $(O C)$, total $N(N), C / N$ ratio $(C / N)$, phosphorous $(P)$, calcium (Ca), magnesium $(\mathrm{Mg})$ and $\mathrm{Ca} / \mathrm{Mg}$ ratio $(\mathrm{Ca} / \mathrm{Mg})$ in response to management with different cover plants.

\begin{tabular}{|c|c|c|c|c|}
\hline Cover plants & $\begin{array}{l}\text { SOM } \\
\left(\mathrm{g} \mathrm{dm}^{-3}\right)\end{array}$ & $\begin{array}{l}\text { OC } \\
\left(\mathrm{g} \mathrm{dm}^{-3}\right)\end{array}$ & $\begin{array}{l}N \\
\left(\mathrm{~g} \mathrm{dm}^{-3}\right)\end{array}$ & $\mathrm{C} / \mathrm{N}$ \\
\hline Canavalia ensiformis & $6.49 \mathrm{~cd}$ & $3.77 \mathrm{~cd}$ & $0.99 \mathrm{~cd}$ & $3.52 \mathrm{~b}$ \\
\hline Dolichos lablab & $11.49 \mathrm{a}$ & $6.68 \mathrm{a}$ & $1.47 \mathrm{a}$ & $3.91 \mathrm{ab}$ \\
\hline Mucuna aterrima & $10.40 a b$ & $6.04 a b$ & $1.29 \mathrm{ab}$ & $4.50 \mathrm{a}$ \\
\hline Mucuna pruriens & $4.74 d$ & $2.75 d$ & $0.74 \mathrm{e}$ & $3.53 \mathrm{ab}$ \\
\hline C. ochroleuca & $6.77 \mathrm{~cd}$ & $3.93 \mathrm{~cd}$ & 0.91 cde & $4.08 \mathrm{ab}$ \\
\hline C. breviflora & $6.77 \mathrm{~cd}$ & $3.93 \mathrm{~cd}$ & $0.89 \mathrm{de}$ & $4.30 \mathrm{ab}$ \\
\hline C. spectabilis & $8.50 \mathrm{bc}$ & $4.94 \mathrm{bc}$ & $1.14 \mathrm{bc}$ & $3.91 \mathrm{ab}$ \\
\hline CV (\%) & 26.33 & 26,33 & 18.15 & 19.25 \\
\hline Cover plants & $\begin{array}{l}P \\
\left(\mathrm{mg} \mathrm{dm}^{-3}\right)\end{array}$ & $\begin{array}{l}\mathrm{Ca} \\
\left(\mathrm{mmol} \mathrm{dm}^{-3}\right)\end{array}$ & $\begin{array}{l}\mathrm{Mg} \\
\left(\mathrm{mmol} \mathrm{dm}^{-3}\right)\end{array}$ & $\mathrm{Ca} / \mathrm{Mg}$ \\
\hline Canavalia ensiformis & $5.02 \mathrm{~b}$ & $20.33 \mathrm{de}$ & $10.74 \mathrm{c}$ & $2.57 \mathrm{~b}$ \\
\hline Dolichos lablab & $8.41 \mathrm{a}$ & $25.91 \mathrm{bcd}$ & $8.70 \mathrm{c}$ & $3.91 \mathrm{a}$ \\
\hline Mucuna aterrima & $4.64 \mathrm{~b}$ & $32.51 \mathrm{a}$ & $15.88 \mathrm{ab}$ & $2.06 \mathrm{bc}$ \\
\hline Mucuna pruriens & $4.17 \mathrm{~b}$ & $15.75 \mathrm{e}$ & $10.68 \mathrm{c}$ & $1.47 \mathrm{c}$ \\
\hline C. ochroleuca & $3.54 \mathrm{~b}$ & $25.41 \mathrm{~cd}$ & $15.78 \mathrm{~b}$ & $1.60 \mathrm{c}$ \\
\hline C. breviflora & $4.65 \mathrm{~b}$ & $31.44 a b$ & $16.01 \mathrm{ab}$ & $1.97 \mathrm{bc}$ \\
\hline C. spectabilis & $4.94 \mathrm{~b}$ & $26.65 \mathrm{abc}$ & $19.02 \mathrm{a}$ & $1.39 \mathrm{c}$ \\
\hline CV (\%) & 35.86 & 18.28 & 18.10 & 33.52 \\
\hline
\end{tabular}
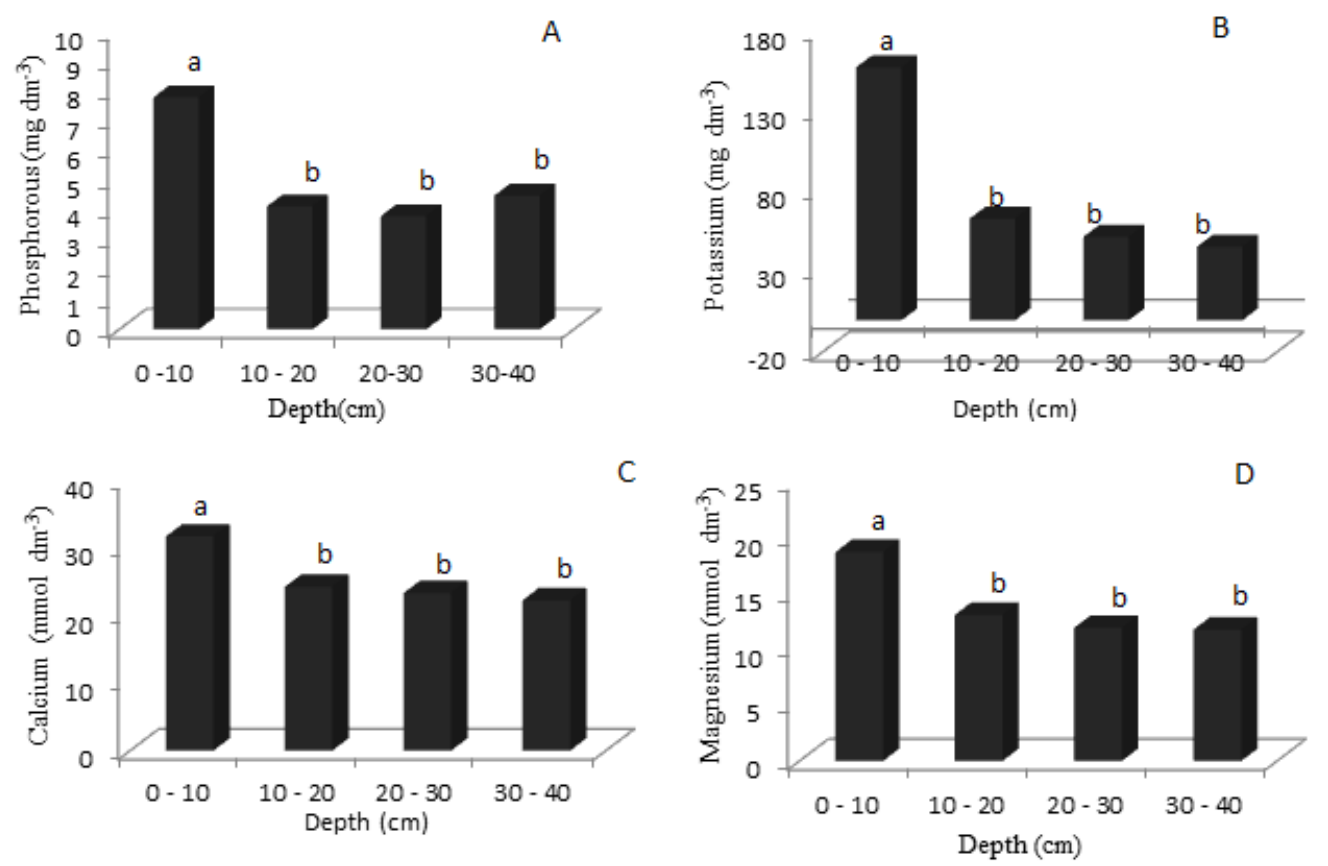

Figure 4. Mean levels of phosphorous (A), potassium (B), calcium (C) e magnesium (D) of soil function of different sampling depths. Equal letters on bars do not differ statistically from each other by tukey test at $1 \%$ probability.

Table 5. Mean values of $\mathrm{pH}$, potential acidity $(\mathrm{H}+\mathrm{Al})$, sum of bases $(\mathrm{SB})$, Cation Exchange capacity (CEC), base saturation (V\%) and aluminum saturation $(\% \mathrm{~m})$ in response to management with different cover plants.

\begin{tabular}{|c|c|c|c|c|c|c|}
\hline Cover plants & $\mathrm{pH}$ & $\mathrm{H}+\mathrm{Al}$ & 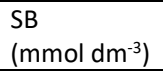 & 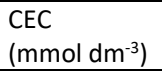 & V\% & $\% \mathrm{~m}$ \\
\hline Canavalia ensiformis & $4.41 \mathrm{c}$ & $30.11 \mathrm{a}$ & $32.79 \mathrm{c}$ & $62.91 \mathrm{abc}$ & $52,82 \mathrm{~d}$ & $22,5 \mathrm{~b}$ \\
\hline Dolichos lablab & $4.67 \mathrm{~b}$ & $21.92 b$ & $36.80 \mathrm{bc}$ & $58.72 \mathrm{c}$ & $60,78 \mathrm{c}$ & $7,70 \mathrm{c}$ \\
\hline Mucuna aterrima & $4.83 \mathrm{~b}$ & $21.85 b$ & $50.29 \mathrm{a}$ & $72.15 \mathrm{a}$ & $69,34 a b$ & $4,90 \mathrm{c}$ \\
\hline Mucuna pruriens & $4.29 \mathrm{c}$ & 32.27 a & $28.56 \mathrm{c}$ & $60.84 \mathrm{bc}$ & $47,37 d$ & $34,72 \mathrm{a}$ \\
\hline C. ochroleuca & $4.81 \mathrm{~b}$ & 20.18 bc & $43.14 a b$ & $63.33 \mathrm{abc}$ & $67,70 \mathrm{bc}$ & $4,45 c$ \\
\hline C. breviflora & $5.30 \mathrm{a}$ & $15.34 \mathrm{c}$ & $49.71 \mathrm{a}$ & $65.06 \mathrm{abc}$ & $76,21 \mathrm{a}$ & $1,78 \mathrm{c}$ \\
\hline C. spectabilis & $5.32 \mathrm{a}$ & $21.43 \mathrm{bc}$ & $47.87 \mathrm{a}$ & $69.31 \mathrm{ab}$ & $67,87 \mathrm{bc}$ & $5,28 \mathrm{c}$ \\
\hline CV (\%) & 3.53 & 20.84 & 16.05 & 11.63 & 8,87 & 30,66 \\
\hline
\end{tabular}

\footnotetext{
Means followed by the same letter in the column do not differ statistically by Tukey test at $5 \%$ probability.
} 
Table 6. Unfolding of the significant interaction between cover plants and sampling depth for organic matter, organic carbon and $\mathrm{N}$-total contents.

\begin{tabular}{|c|c|c|c|c|}
\hline \multirow[b]{2}{*}{ Cover plants } & \multicolumn{4}{|c|}{ Organic matter $\left(\mathrm{g} \mathrm{dm}^{-3}\right)$} \\
\hline & $0-10$ & $10-20$ & $20-30$ & $30-40$ \\
\hline Canavalia ensiformis & $9.70 \mathrm{cA}$ & $6.53 \mathrm{bAB}$ & $6.53 \mathrm{bAB}$ & $3.20 \mathrm{bB}$ \\
\hline Dolichos lablab & $21.57 \mathrm{aA}$ & $12.17 \mathrm{aB}$ & $7.13 \mathrm{aC}$ & $5.08 \mathrm{aC}$ \\
\hline Mucuna aterrima & $16.79 \mathrm{abA}$ & $11.15 \mathrm{aB}$ & $7.99 \mathrm{aC}$ & $5.68 \mathrm{aC}$ \\
\hline Mucuna pruriens & $8.67 \mathrm{cA}$ & $3.80 \mathrm{cB}$ & $3.37 \mathrm{cB}$ & $3.11 \mathrm{bB}$ \\
\hline C. ochroleuca & $13 . .0 \mathrm{bcA}$ & $5.25 \mathrm{cB}$ & $5.08 \mathrm{bB}$ & $2.94 \mathrm{bB}$ \\
\hline C. breviflora & 13.88 bcA & $4.65 \mathrm{cB}$ & $4.99 \mathrm{bB}$ & $3.54 \mathrm{bB}$ \\
\hline \multirow[t]{2}{*}{ C. spectabilis } & $17.64 \mathrm{abA}$ & $6.79 \mathrm{bB}$ & $5.85 \mathrm{bB}$ & $3.71 \mathrm{bB}$ \\
\hline & \multicolumn{4}{|c|}{ Organic carbon $\left(\mathrm{g} \mathrm{dm}^{-3}\right)$} \\
\hline Cover plants & $0-10$ & $10-20$ & $20-30$ & $30-40$ \\
\hline Canavalia ensiformis & $5.63 \mathrm{cA}$ & $3.80 \mathrm{bB}$ & $3.80 \mathrm{bB}$ & $1.86 \mathrm{bC}$ \\
\hline Dolichos lablab & $12.54 \mathrm{aA}$ & $7.08 \mathrm{aB}$ & $4.14 \mathrm{aC}$ & $3.95 \mathrm{aC}$ \\
\hline Mucuna aterrima & $9.76 \mathrm{abA}$ & $6.48 \mathrm{aB}$ & $4.64 \mathrm{aC}$ & $3.30 \mathrm{aC}$ \\
\hline Mucuna pruriens & $5.04 \mathrm{cA}$ & $2.21 \mathrm{bB}$ & $1.96 \mathrm{bB}$ & $1.81 \mathrm{bB}$ \\
\hline C. ochroleuca & $8.02 \mathrm{bA}$ & $3.05 \mathrm{bB}$ & $2.95 \mathrm{bB}$ & $1.71 \mathrm{bB}$ \\
\hline C. breviflora & $8.07 \mathrm{bA}$ & $2.70 \mathrm{bB}$ & $2.90 \mathrm{bB}$ & $2.06 \mathrm{bB}$ \\
\hline \multirow[t]{2}{*}{ C. spectabilis } & $8.26 \mathrm{bA}$ & $3.95 \mathrm{bB}$ & $3.40 \mathrm{bB}$ & $2.16 \mathrm{bB}$ \\
\hline & \multicolumn{4}{|c|}{ N-total $\left(\mathrm{g} \mathrm{dm}^{-3}\right)$} \\
\hline Cover plants & $0-10$ & $10-20$ & $20-30$ & $30-40$ \\
\hline Canavalia ensiformis & $1.07 \mathrm{cA}$ & $1.11 \mathrm{abA}$ & $1.04 \mathrm{aA}$ & $0.76 \mathrm{aB}$ \\
\hline Dolichos lablab & $2.54 \mathrm{aA}$ & $1.60 \mathrm{aB}$ & $1.08 \mathrm{aC}$ & $0.68 \mathrm{aD}$ \\
\hline Mucuna aterrima & $1.89 \mathrm{aA}$ & $1.58 \mathrm{aB}$ & $1.12 \mathrm{aC}$ & $0.90 \mathrm{aD}$ \\
\hline Mucuna pruriens & $1.04 \mathrm{cA}$ & $0.66 \mathrm{bB}$ & $0.64 \mathrm{bB}$ & $0.62 \mathrm{aB}$ \\
\hline C. ochroleuca & $1.67 \mathrm{bA}$ & $0.72 \mathrm{bB}$ & $0.66 \mathrm{bB}$ & $0.60 \mathrm{aB}$ \\
\hline C. breviflora & $1.52 \mathrm{bA}$ & $0.69 \mathrm{bB}$ & $0.65 \mathrm{bB}$ & $0.70 \mathrm{aB}$ \\
\hline C. spectabilis & $1.69 \mathrm{bA}$ & $1.13 \mathrm{abB}$ & $0.85 \mathrm{bB}$ & $0.71 \mathrm{aB}$ \\
\hline
\end{tabular}

Lowercase letters separate the means within each column, and the uppercase separates the averages within the row. Equal letters do not differ from each other by the Tukey test at $1 \%$ probability

Table 7. Unfolding of the significant interaction between cover plants and sampling depth for phosphorus, magnesium, calcium and calcium/magnesium ratio.

\begin{tabular}{|c|c|c|c|c|}
\hline \multirow[b]{2}{*}{ Cover plants } & \multicolumn{4}{|c|}{ Phosphorous ( $\left.\mathrm{mg} \mathrm{dm}^{-3}\right)$} \\
\hline & $0-10$ & $10-20$ & $20-30$ & $30-40$ \\
\hline Canavalia ensiformis & $7.28 \mathrm{bA}$ & $5.47 a B$ & $4.47 \mathrm{aBC}$ & $2.85 \mathrm{bC}$ \\
\hline Dolichos lablab & $17.20 \mathrm{aA}$ & $6.59 \mathrm{aB}$ & $5.37 \mathrm{aB}$ & $5.59 \mathrm{aB}$ \\
\hline Mucuna aterrima & $7.13 \mathrm{bA}$ & $3.76 \mathrm{bB}$ & $3.23 \mathrm{bB}$ & $3.43 \mathrm{bB}$ \\
\hline Mucuna pruriens & $6.69 \mathrm{bA}$ & $2.88 \mathrm{cB}$ & $3.14 \mathrm{bB}$ & $3.97 \mathrm{bB}$ \\
\hline C. ochroleuca & $3.93 \mathrm{cA}$ & $2.86 \mathrm{cA}$ & $3.43 \mathrm{bA}$ & $2.89 \mathrm{bA}$ \\
\hline C. breviflora & $4.07 \mathrm{cA}$ & $4.44 \mathrm{bA}$ & $3.91 \mathrm{bA}$ & $2.92 \mathrm{bA}$ \\
\hline \multirow[t]{2}{*}{ C. spectabilis } & $8.15 \mathrm{bA}$ & $3.89 \mathrm{bB}$ & $2.94 \mathrm{bB}$ & $2.79 \mathrm{bB}$ \\
\hline & \multicolumn{4}{|c|}{ Magnesium $\left(\mathrm{mmol} \mathrm{dm}^{-3}\right)$} \\
\hline Cover plants & $0-10$ & $10-20$ & $20-30$ & $30-40$ \\
\hline Canavalia ensiformis & $16.05 \mathrm{bA}$ & $11.17 \mathrm{bAB}$ & $8.52 \mathrm{cdB}$ & $7.22 \mathrm{bB}$ \\
\hline Dolichos lablab & $19.63 \mathrm{bA}$ & $6.90 \mathrm{cB}$ & $4.36 \mathrm{~dB}$ & $4.11 \mathrm{cB}$ \\
\hline Mucuna aterrima & $18.68 \mathrm{bA}$ & $15.22 \mathrm{abA}$ & $13.90 \mathrm{bcA}$ & $15.74 \mathrm{aA}$ \\
\hline Mucuna pruriens & $13.20 \mathrm{bA}$ & $9.54 \mathrm{bA}$ & $10.12 \mathrm{cdA}$ & $9.86 \mathrm{bA}$ \\
\hline C. ochroleuca & $18.66 \mathrm{bA}$ & $15.26 \mathrm{abA}$ & $15.17 \mathrm{abA}$ & $14.01 \mathrm{aA}$ \\
\hline C. breviflora & $18.66 \mathrm{bA}$ & $15.29 \mathrm{abA}$ & 14.47abA & $15.62 \mathrm{aA}$ \\
\hline \multirow[t]{2}{*}{ C. spectabilis } & $25.97 \mathrm{aA}$ & $17.86 \mathrm{aB}$ & $16.70 \mathrm{aB}$ & $15.56 \mathrm{aB}$ \\
\hline & \multicolumn{4}{|c|}{ Calcium $\left(\mathrm{mmol} \mathrm{dm}^{-3}\right)$} \\
\hline Cover plants & $0-10$ & $10-20$ & $20-30$ & $30-40$ \\
\hline Canavalia ensiformis & $24.30 \mathrm{bA}$ & $19.71 \mathrm{cA}$ & $18.44 \mathrm{cA}$ & $18.86 \mathrm{bA}$ \\
\hline Dolichos lablab & $39.64 \mathrm{aA}$ & $21.09 \mathrm{bcB}$ & $21.34 \mathrm{bB}$ & $21.56 \mathrm{abB}$ \\
\hline Mucuna aterrima & $33.45 \mathrm{abA}$ & $35.10 \mathrm{aA}$ & $31.96 \mathrm{aA}$ & $29.53 \mathrm{aA}$ \\
\hline Mucuna pruriens & $19.58 \mathrm{cA}$ & $14.24 \mathrm{cA}$ & $14.20 \mathrm{cA}$ & $14.98 \mathrm{bA}$ \\
\hline C. ochroleuca & $30.69 \mathrm{abA}$ & 24.98 bA & $23.63 \mathrm{bA}$ & $22.36 \mathrm{abA}$ \\
\hline C. breviflora & $35.59 \mathrm{abA}$ & $30.52 \mathrm{abA}$ & $31.52 \mathrm{aA}$ & $28.12 \mathrm{aA}$ \\
\hline C. spectabilis & $39.16 \mathrm{aA}$ & $24.27 \mathrm{bcB}$ & $22.50 \mathrm{bB}$ & $20.69 \mathrm{abB}$ \\
\hline \multirow[t]{2}{*}{ Cover plants } & \multicolumn{4}{|c|}{ Ratio $\mathrm{Ca} \mathrm{Mg}$} \\
\hline & $0-10$ & $10-20$ & $20-30$ & $30-40$ \\
\hline Canavalia ensiformis & $1.52 \mathrm{bB}$ & $2.00 \mathrm{bB}$ & $2.95 \mathrm{bAB}$ & $3.80 \mathrm{bA}$ \\
\hline Dolichos lablab & $2.04 \mathrm{aB}$ & $3.11 \mathrm{aB}$ & $5.09 \mathrm{aA}$ & $5.40 \mathrm{aA}$ \\
\hline Mucuna aterrima & $1.81 \mathrm{bA}$ & $2.32 \mathrm{bA}$ & $2.23 \mathrm{bA}$ & $1.86 \mathrm{cA}$ \\
\hline Mucuna pruriens & $1.47 \mathrm{bA}$ & $1.49 \mathrm{bA}$ & $1.40 \mathrm{bA}$ & $1.51 \mathrm{cA}$ \\
\hline C. ochroleuca & $1.64 \mathrm{bA}$ & $1.62 \mathrm{bA}$ & $1.55 \mathrm{bA}$ & $1.60 \mathrm{cA}$ \\
\hline C. breviflora & $1.90 \mathrm{bA}$ & $1.98 \mathrm{bA}$ & $2.18 \mathrm{bA}$ & $1.80 \mathrm{cA}$ \\
\hline C. spectabilis & $1.53 \mathrm{bA}$ & $1.36 \mathrm{bA}$ & $1.34 \mathrm{bA}$ & $1.32 \mathrm{cA}$ \\
\hline
\end{tabular}


Table 8. Unfolding of the significant interaction between cover plants and sampling depth for $\mathrm{pH}$, base saturation (SB) and cation exchange capacity (CEC).

\begin{tabular}{|c|c|c|c|c|}
\hline \multirow[b]{2}{*}{ Cover plants } & \multicolumn{4}{|c|}{$\mathrm{pH}$} \\
\hline & $0-10$ & $10-20$ & $20-30$ & $30-40$ \\
\hline Canavalia ensiformis & $4.41 \mathrm{bA}$ & $4.23 \mathrm{bA}$ & $4.33 \mathrm{bA}$ & $4.68 \mathrm{bA}$ \\
\hline Mucuna aterrima & $4.83 \mathrm{bA}$ & $4.84 \mathrm{bA}$ & $4.85 \mathrm{bA}$ & $4.80 \mathrm{bA}$ \\
\hline Mucuna pruriens & $4.37 \mathrm{bA}$ & $4.24 \mathrm{bA}$ & $4.28 \mathrm{bA}$ & $4.27 \mathrm{bA}$ \\
\hline C. ochroleuca & $5.04 \mathrm{aA}$ & $4.71 \mathrm{bA}$ & $4.70 \mathrm{bA}$ & $4.80 \mathrm{bA}$ \\
\hline C. breviflora & $5.17 \mathrm{aA}$ & $5.23 \mathrm{aA}$ & $5.33 \mathrm{aA}$ & $5.27 \mathrm{aA}$ \\
\hline \multirow[t]{2}{*}{ C. spectabilis } & $4.92 \mathrm{bA}$ & $4.60 \mathrm{bA}$ & $4.64 \mathrm{bA}$ & $4.73 \mathrm{bA}$ \\
\hline & \multicolumn{4}{|c|}{$\mathrm{SB}\left(\mathrm{mmol} \mathrm{dm^{-3 } )}\right.$} \\
\hline Cover plants & $0-10$ & $10-20$ & $20-30$ & $30-40$ \\
\hline Canavalia ensiformis & $43.49 \mathrm{bcA}$ & $32.48 \mathrm{cdB}$ & $28.19 \mathrm{bB}$ & $27.00 \mathrm{bB}$ \\
\hline Dolichos lablab & $63.33 \mathrm{aA}$ & $29.75 \mathrm{~dB}$ & $27.11 \mathrm{bB}$ & $27.00 \mathrm{bB}$ \\
\hline Mucuna aterrima & $56.06 \mathrm{abA}$ & $51.85 \mathrm{aA}$ & $46.93 \mathrm{aA}$ & $46.32 \mathrm{aA}$ \\
\hline Mucuna pruriens & $36.65 \mathrm{cA}$ & $25.66 \mathrm{dA}$ & 25.94 bA & $26.00 \mathrm{bA}$ \\
\hline C. breviflora & $59.12 \mathrm{abA}$ & 47.34 bA & $47.31 \mathrm{aA}$ & $45.07 \mathrm{aA}$ \\
\hline \multirow[t]{2}{*}{ C. spectabilis } & $69.77 \mathrm{aA}$ & $43.58 \mathrm{bB}$ & $40.67 \mathrm{abB}$ & $37.46 \mathrm{abB}$ \\
\hline & \multicolumn{4}{|c|}{$\mathrm{CEC}\left(\mathrm{mmol} \mathrm{dm}^{-3}\right)$} \\
\hline Cover plants & $0-10$ & $10-20$ & $20-30$ & $30-40$ \\
\hline Canavalia ensiformis & $70.85 \mathrm{bcA}$ & $69.77 \mathrm{aA}$ & $58.97 \mathrm{bB}$ & $52.05 \mathrm{abB}$ \\
\hline Dolichos lablab & $86.37 \mathrm{abA}$ & $56.51 \mathrm{aB}$ & $47.28 \mathrm{bB}$ & $44.72 \mathrm{bB}$ \\
\hline Mucuna aterrima & $79.41 \mathrm{bcA}$ & $74.76 \mathrm{aA}$ & $66.66 \mathrm{aA}$ & $67.76 \mathrm{aA}$ \\
\hline Mucuna pruriens & $65.36 \mathrm{cA}$ & $62.64 \mathrm{aA}$ & 57.26 bA & $58.08 \mathrm{abA}$ \\
\hline C. ochroleuca & $72.90 \mathrm{bcA}$ & $63.32 \mathrm{aA}$ & $60.34 \mathrm{abA}$ & $56.74 \mathrm{abA}$ \\
\hline C. breviflora & $75.62 \mathrm{bcA}$ & $62.28 \mathrm{aA}$ & $62.57 \mathrm{abA}$ & $59.76 \mathrm{abA}$ \\
\hline C. spectabilis & $92.69 \mathrm{aA}$ & $66.06 \mathrm{aB}$ & $61.41 \mathrm{abB}$ & $57.08 \mathrm{abB}$ \\
\hline
\end{tabular}

This effect may be associated with the superficial application of limestone. In all treatments, the contents of $\mathrm{Ca}^{2+}$ and $\mathrm{Mg}^{2+}$ (RAIJ et al., 1996) were high up to at least $10 \mathrm{~cm}$ deep. Such behavior was not observed in upper sampling layers, i.e., there was no statistical difference between the other sampling layers.

\section{Materials and methods}

\section{Characterization of the experimental área}

The experiment was conducted from August 2019 to March 2020, in the experimental area of the Federal Institute of Education, Science and Technology of Rondônia, Colorado do Oeste Campus, in the municipality of Colorado do Oeste, $\mathrm{RO}, \mathrm{Brazil}$, at the geographic coordinates $13^{\circ} 06^{\prime} \mathrm{S}$ and $60^{\circ}$ $29^{\prime}$ W, with an average altitude of 407 meters. According to Köppen's classification, the climate is Awa, tropical hot and humid with two well-defined seasons. Mean temperature and rainfall data during the experiment were obtained from the database of the National Institute of Meteorology (Figure 1). Chemical characterization of the soil was performed in the layers of $0-10 \mathrm{~cm}, 10-20 \mathrm{~cm}, 20-30 \mathrm{~cm}$ and $30-40 \mathrm{~cm}$, with samples collected before the installation of the experiment, and the data are presented in Table 1. The particle-size analysis at the depth of $0-10 \mathrm{~cm}$ showed $343 \mathrm{~g}$ $\mathrm{dm}^{-3}$ of clay, $479 \mathrm{~g} \mathrm{dm}^{-3}$ of sand and $178 \mathrm{~g} \mathrm{dm}^{-3}$ of silt. Soil correction was performed thirty days prior to sowing, based on the results of soil analysis in the $0-10 \mathrm{~cm}$ layer, using the dose of $1230 \mathrm{~kg} \mathrm{ha}^{-1}$ of dolomitic limestone (RNV 97\%) in order to increase base saturation to $65 \%$.

\section{Experimental design}

The experimental design was completely randomized, arranged in a factorial scheme $7 \times 4$, consisting of seven species of cover crops cultivated prior to the maize crop (Crotalaria spectabilis, Crotalaria breviflora, Crotalaria ochroleuca, Mucuna aterrima, Mucuna pruriens, Dolichos lablab and Canavalia ensiformis) and four sampling depths $(0-10 \mathrm{~cm}, 10-20 \mathrm{~cm}, 20-30 \mathrm{~cm}$ and $30-40 \mathrm{~cm})$, with four replicates.

\section{Soil preparation and planting}

Primary soil tillage included plowing and harrowing (disc harrow) up to $15 \mathrm{~cm}$ deep, while secondary tillage includes the breaking of clods and leveling of the experimental area. Basal fertilization was carried out broadcast, with subsequent incorporation, applying $400 \mathrm{~kg} \mathrm{ha}^{-1}$ of the formulation $0-20-20$ to provide $120 \mathrm{~kg} \mathrm{ha}^{-1}$ of $\mathrm{P}_{2} \mathrm{O}_{5}$ and $80 \mathrm{~kg}$ ha $^{-1}$ of $\mathrm{K}_{2} \mathrm{O}$, respectively.

The planting furrows were mechanically opened at depths between 5 and $7 \mathrm{~cm}$, according to the established spacing. Sowing was performed manually. The different amounts of seeds adopted were based on recommendations (Table 2). Seed inoculation was not performed in any of the legume cover plants. Each experimental unit was composed of 8 rows with length of 4 meters, spaced by $0.45 \mathrm{~m}$ between rows and $0.20 \mathrm{~m}$ between plants. The six central rows were considered as usable plot, disregarding $0.5 \mathrm{~m}$ on each end of the plot.

At fifteen and thirty days after emergence of the cover crops, plants were sprayed with insecticide containing the active ingredients (a.i.) Imidacloprid $100 \mathrm{~g} / \mathrm{L}$ and Beta- 
cyfluthrin $12.5 \mathrm{~g} / \mathrm{L}$, chemical groups Neonicotinoid (Imidacloprid) and Pyrethroid (Beta-cyfluthrin), with recommendation of $750-1000 \mathrm{~mL} /$ ha for the control of Lagria villosa, Diabrotica speciosa, Cerotoma arcuata and Edessa meditabunda.

\section{Desiccation and determination of dry mass production}

At full flowering, the cover crops, except Canavalia ensiformis (collected at the beginning of grain filling), were desiccated with the herbicide glyphosate $(1.920 \mathrm{~g}$ a.i. ha-1) and then managed with manual mower at $0.05 \mathrm{~m}$ height from the soil surface, aiming at the standardization of the area. However, before desiccation, dry matter yield and macronutrient contents were evaluated in the shoots of the different cover crops. For dry matter determination, a square $(0.50 \mathrm{~m} \times 0.50 \mathrm{~m})$ was used to demarcate the area of the plot, in which the sample was collected (close to the soil). It weighed to determine the fresh mass, dried in a forced air circulation oven at $65 \stackrel{\circ}{ } \mathrm{C}$ until reaching constant weight, and weighed to determine the dry matter. Subsequently, the samples were ground in a Wiley-type mill and subjected to sulfuric digestion and nitric-perchloric digestion, using the methodology described in Embrapa (2009) to determine leaf contents of macronutrients.

\section{Determination of soil chemical atributes}

In order to determine soil chemical attributes, soil samples were collected at depths of $0-10,10-20,20-30$ and $30-40 \mathrm{~cm}$ after 30 days of decomposition of the cover crops. The soil samples were air dried, passed through a 2-mm-mesh sieve, homogenized and subjected to evaluations of $\mathrm{pH}$ values and contents of available $\mathrm{P}$, exchangeable $\mathrm{K}^{+}, \mathrm{Ca}^{2+}$ and $\mathrm{Mg}^{2+}, \mathrm{Al}$, $\mathrm{H}+\mathrm{Al}, \mathrm{SB}, \mathrm{CEC}$ and $\% \mathrm{~V}$, using the methodology described in Embrapa (2009). Organic matter and organic carbon stocks were determined by the methodology proposed by Cambardella and Elliot (1992), and soil N-total was determined by the Kjeldahl method, according to Tedesco et al. (1995).

\section{Statistical analysis}

The data were subjected to the normality test (Shapiro-Wilk) and analysis of variance, and the effects of the cover plants on nutrient absorption were evaluated by Tukey test at $5 \%$ probability level, while the effects between cover plants and sampling depth were evaluated by Tukey test at $1 \%$ probability level using the statistical program Sisvar.

\section{Conclusions}

Cultivation of Crotalaria spectabilis, Crotalaria ochroleuca and Crotalaria breviflora provided higher dry matter yield. The species Dolichos lablab stood out in the accumulation of nitrogen, phosphorus, calcium and sulfur in the leaves at full flowering. The contents of organic matter, total carbon, $\mathrm{C} / \mathrm{N}$ ratio, $\mathrm{N}$-total, $\mathrm{P}, \mathrm{K}, \mathrm{Ca}^{2+}$ and $\mathrm{Mg}^{2+}$ of the soil were higher at the depth of $0-10 \mathrm{~cm}$, with reduction in subsurface layers.

The species Dolichos lablab and Mucuna pruriens are efficient in terms of the supply of organic matter, organic carbon, $\mathrm{C} / \mathrm{N}$ ratio, $\mathrm{N}$-total, phosphorus, calcium and $\mathrm{Ca} / \mathrm{Mg}$ ratio of the soil, causing a direct impact on the fertility of the surface layers, up to $10 \mathrm{~cm}$ deep.
Cultivation of Crotalaria breviflora and Crotalaria spectabilis caused variation in the contents of soil exchangeable bases, with direct correlation with the values of $\mathrm{pH}, \mathrm{SB}$ and CEC.

\section{Acknowledgments}

The authors thank the Foundation for the Development of Scientific and Technological Actions and Research of the Rondonia State and the Federal Institute of Education Science and Technology of Rondônia for providing the resources to conduct the study and for granting scientific initiation scholarships.

\section{References}

Andrade Neto RC et al (2008) Adubação verde: uma alternativa sustentável para o Brasil. Revista Verde. 3(1):16-20.

Almeida JA, Bertol I, Leite D, Amaral AJ, Zoldan Jr WA (2005) Propriedades químicas de um Cambissolo Húmico sob preparo convencional e semeadura direta após seis anos de cultivo. Rev Bras de Cien Solo. 29:437-445.

Azevedo DMP, Leite LFC, Teixeira Neto ML, Dantas JS (2007) Atributos físicos e químicos de um Latossolo Amarelo e distribuição do sistema radicular da soja sob diferentes sistemas de preparo no cerrado maranhense. Rev Cien Agro. 38:32-40.

Barros DL,Gomide PHO, Carvalho GJ (2013) Plantas de cobertura e seus efeitos na cultura em sucessão. Bioscience J. 29(2): 308-318.

Basche AD, Miguez FE, Kaspar TC, Castellano MJ (2014) Do cover crops increase or decrease nitrous oxide emissions in agroecosystems? A meta-analysis. J of Soil and Water Conservation. 69(6): 471-482.

Bertiol ACT. Efeito de plantas de cobertura em atributos químicos do solo. Jaboticabal: UNESP, 2014, 50 p. Dissertação (Mestrado) - Curso de Pós-Graduação em Agronomia, Área de Concentração em Ciência do Solo, Universidade Estadual Paulista, Faculdade de Ciências Agrárias e Veterinárias, 2014.

Boer CA, Assis RL, Silva GP, Braz AJBP, Barroso ALL, Filho AC, Pires FR (2008) Biomassa, decomposição e cobertura do solo ocasionada por resíduos culturais de três espécies vegetais na região centro-oeste do Brasil. Rev Bras Cien Solo. 32(2): 843-851.

Bolan NS, Adriano DC, Kunhikrishnan A, James T, McDowell R, Senesi N (2011) Dissolved organic matter: biogeochemistry, dynamics, and environmental significance in soils. Advances in Agronomy. 110:1-75.

Bressan SB, Nóbrega JCA, Nóbraga RSA, Barbosa RN, Sousa L (2013) Plantas de cobertura e qualidade química de Latossolo Amarelo sob plantio direto no cerrado maranhense. Rev Bras Eng Agric e Amb. 17(4):.371-378.

Canellas LP, Velloso ACX, Marciano CR, Ramalho JFGP, Rumjanek VM, Resende CE, Santos GA (2003) Propriedades químicas de um Cambissolo cultivado com cana-de-açúcar, com preservação do palhiço e adição de vinhaça por longo tempo. Rev Bras Cien Solo. 27: 935-944.

Cardoso DP, Silva MLN, Carvalho GJ, Freitas DAF, Avanzi JC (2013) Espécies de plantas de cobertura no recondicionamento químico e físico do solo. Rev Bras Cien Agra. 8(3):375-382. 
Conceição PC, Dieckon J, Bayer C (2013) Combined role of notillage and cropping systems in soil carbon stocks and stabilization. Soil and Tillage Res. 129: p.4047.

Calegari A (1995) Leguminosas para adubação de verão no Paraná. Londrina, PR: IAPAR, $118 \mathrm{p}$.

Cambardella CA, Elliot ET (1992) Particulate soil organic matter changes across a grassland cultivation sequence. Soil Scie Soc of America J. 56: 777-783.

Carvalho AM de, Coser TR, Rein TA, Dantas RA, Silva RR, Souza KW (2015). Manejo de plantas de cobertura na floração e na maturação fisiológica e seu efeito na produtividade do milho. Pesq Agrop Bras. 50(7): 551-561.

Conab. 2020. Acompanhamento da Safra Brasileira de Grãos 2019/2020: Sexto Levantamento, Março/2020, Companhia Nacional de Abastecimento. Brasília, CONAB, 89p.

Ensinas SC, Serra AP, Marchetti ME, Silva EF da, Prado EAF do, Lourente ERP, Altomar PH, Potrich DC, Martinez MA, Conrad V do A, Jesus MV, El Kadri TC (2016) Cover crops affect on soil organic matter fractions under no till system. Aust J Crop Scie. 10:503-512.

Empresa Brasileira de Pesquisa Agropecuária - Embrapa (2009) Manual de análises químicas de solos, plantas e fertilizantes.- 2. Ed, Brasília., Embrapa Informação Tecnológica. $627 \mathrm{p}$.

Faccin FC, Marchetti ME, Serra AP, Ensinas SC (2016) Frações granulométricas da matéria orgânica do solo em consórcio de milho safrinha com capim-marandu sob fontes de nitrogênio. Pesq Agrop Bras. 51(2):2000-2009.

Fischlerab M, Wortmann CS, Feil B (1999) Crotalaria (C.ochroleuca $\mathrm{G}$ Don.) as a green manure in maize-bean cropping systems in Uganda. Field Crops Res. 61(2): 97107.

Lima CEP, Fontenelle MR, Madeira NR, Silva J, Guedes IMR, Silva LRB, Soares DC (2016) Compartimentos de carbono orgânico em Latossolo cultivado com hortaliças sob diferentes manejos. Pesquisa Agropecuária Brasileira, 51(4):.378-387.

Marques JDO, Luizão FJ, Teixeira WG, Ferreira SJF (2012) Variações do carbono orgânico dissolvido e de atributos físicos do solo sob diferentes sistemas de uso da terra na Amazônia Central. Rer Bras Cien Solo. 36: 611-622.

Mukherjee A, Lal R (2015) Short-term effects of cover cropping on the quality of a Typic Argiaquolls in Central Ohio. Catena. 131(2): 125-129.

Padovan MP, Carneiro LF, Moitinho MR, Felisberto G, Carneiro DNM, Motta IS (2014) Dinâmica de acúmulo de massa e nutrientes pela Crotalaria juncea para fins de adubação verde e o estádio adequado para seu manejo. Cadernos Agro. 9(4): 1-4.

Padovan MP, Motta IS, Carneiro LF, Moitinho MR, Fernandes SSL (2011) Acúmulo de fitomassa e nutrientes e estádio mais adequado de manejo do feijão-de-porco para fins de adubação verde. Rev Bras Agro. 6(3): 182-190.
Pereira AP, Schoffel A, Koefender J, Camera JN, Golle DP, Horn RC (2017) Ciclagem de nutrientes por plantas de cobertura de verão. Rev Cien Agra. 40(4): 799-807.

Raij Bvan, Cantarella H, Quaggio JA, Furlani AMC (1997) Recomendações de adubação e calagem para o Estado de São Paulo. 2. ed. Campinas: Instituto Agronômico de Campinas, $287 \mathrm{p}$

Salton JC, Mielniczuk J, Bayer C, Fabricio AC, Macedo MCM, Broch DL (2011) Teor e dinâmica do carbono no solo em sistemas de integração lavoura-pecuária. Pesq Agrop Bras. 46: 1349-1356

Santos GG, Marchão RL, Silveira PM, Becquer T (2011) Qualidade física do solo sob sistemas de integração lavoura-pecuária. Pesq Agrop Bras. 46: 1339-1348.

Santos GG, Silveira PM, Marchão RL, Petter FA, Becquer T (2012) Atributos químicos e estabilidade de agregados sob diferentes culturas de cobertura em Latossolo do cerrado. Rev Bras Eng Agri e Amb. 16(11): 1171-1178.

Sidiras N, Pavan MA (1985) Influência do sistema de manejo do solo no seu nível de fertilidade. RevBras Cien Solo. 9(2): 249-254.

Silva MP, Arf O, Sá ME, Abrantes FL, Berti CLF, Souza LCD (2017) Plantas de cobertura e qualidade química e física de Latossolo Vermelho distrófico sob plantio direto. Rev Bras de Cien Agra.12(1): p. 60-67.

Sisti CPJ, Santos HP, Kohhann R, Aalves BJR, Urquiagua S, Boddey RM (2004) Change in carbon and nitrogen stocks in soil under 13 years of conventional or zero tillage in Southern Brazil. Soil and Tillage Res. 76: 39-58.

Smethurst PJ (2011) Soil solution and other soil analyses as indicators of nutrient supply: a review. Forest Ecology and Management, v.138, n.1/3, p.397-411, 2000. Tarifa J. R. Mato Grosso: clima - análise e representação cartográfica. Cuiabá: Entrelinhas. 102 p.

Tedesco MJ, Gianello C, Bissani CA, Bohnen H, Wokweiss SJ (1995) Análises de solo, plantas e outros materiais. 2.a ed. Porto Alegre, UFRGS/Departamento de Solos. 174 p.

Teodoro RB, Oliveira FL, Silva DMN, Fávaro C, Quaresma MAL (2011) Aspectos agronômicos de leguminosas para adubação verde no Cerrado no Alto Vale do Jequitinhonha. Rev Bras Cien Solo. 35(2): 635-643.

Theodoro VCA, Alvarenga MIN, Guimarães RJ, Souza CAS (2003) Alterações químicas em solo submetido a diferentes formas de manejo do cafeeiro. Rev Bras Cien Solo. 27: 1039-1047.

Wutke EB, Calegari A, Wildner LP (2014) Espécies de adubos verdes e plantas de cobertura e recomendações para seu uso. In: Lima Filho, O. F.; Ambrosano, E. J.; Rossi, F.; Carlos, J. A. D. (Ed.). Adubação verde e plantas de cobertura no Brasil: fundamentos e prática. Brasília, DF: Embrapa, p. 59-168. 